\title{
ANALISIS KEMAMPUAN PEMECAHAN MASALAH MATEMATIS DITINJAU DARI RESILIENSI MATEMATIS SISWA SMP
}

\author{
Rizqa Rahmmatiya', Asih Miatun² \\ 1,2 Univesitas Muhammadiyah Prof. DR. HAMKA, JI.Tanah Merdeka, Jakarta, Indonesia \\ Email: rzqrahmatiya7@gmail.com
}

\begin{abstract}
Mathematical problem-solving skills are an important ability for students because problem-solving skills are the basis of even general goals in math learning. Meanwhile, mathematical resilience can support students' mathematical problemsolving skills. This research aims to describe and analyze mathematical problem-solving capabilities reviewed from mathematical resilience in junior high school students. This research is qualitatively descriptive. The subject used in this study was grade VII-B students of SMP Negeri 160 Jakarta. The subjects of this study were 2 people taken using purposive sampling techniques. The research instruments used are tests of mathematical problem-solving skills, mathematical resilience questionnaires, and interview guidelines. Data validation uses time triangulation. Data analysis using constant comparative method with steps: (1) data reduction and categorization; (2) presentation of data; and (3) withdrawal of conclusions. The results showed that students with high mathematical resilience had good mathematical problem-solving skills, as they were able to achieve systematic measures and confidence in solving problems. While students who have resilience are still lacking in mathematical problem-solving skills, because they have not been able to achieve systematic measures in mathematical problem-solving skills, are less conscientious, and tend to give up when faced with difficult questions.
\end{abstract}

Keywords: Mathematical problem-solving skills, math learning, mathematical resilience

\begin{abstract}
ABSTRAK
Kemampuan pemecahan masalah matematis merupakan kemampuan yang penting dimiliki siswa, karena kemampuan pemecahan masalah menjadi dasar bahkan merupakan tujuan umum dalam pembelajaran matematika. Sementara itu resiliensi matematis dapat menunjang kemampuan pemecahan masalah matematis siswa. Penelitian ini bertujuan untuk mendeskripsikan dan menganalisis kemampuan pemecahan masalah matematis ditinjau dari resiliensi matematis pada siswa SMP. Penelitian ini merupakan deskriptif kualitatif. Subjek yang digunakan dalam penelitian ini siswa kelas VII-B SMP Negeri 160 Jakarta. Subjek penelitian ini sebanyak 2 orang yang diambil menggunakan teknik purposive sampling. Instrumen penelitian yang digunakan yaitu tes kemampuan pemecahan masalah matematis, kuesioner resiliensi matematis dan pedoman wawancara. Validasi data menggunakan triangulasi waktu. Analisis data menggunakan metode perbandingan tetap (constant comparative method) dengan langkah: (1) reduksi data dan kategorisasi; (2) penyajian data; dan (3) penarikan kesimpulan. Hasil penelitian menunjukkan bahwa siswa yang memiliki resiliensi matematis tinggi memiliki kemampuan pemecahan masalah matematis yang baik, karena mampu mencapai langkah-langkah yang sistematis dan adanya rasa percaya diri dalam memecahkan masalah. Sedangkan siswa yang memiliki resiliensi sedang masih kurang dalam kemampuan pemecahan masalah matematisnya, karena belum mampu mencapai langkah-lagkah yang sistematis dalam kemampuan pemecahan masalah matematis, kurang teliti dan cendrung menyerah bila dihadapkan soal yang sulit.
\end{abstract}

Kata kunci: Kemampuan pemecahan masalah matematis, pembelajaran matematika, resiliensi matematis

Dikirim: 6 Juli 2020; Diterima: 25 Agustus 2020; Dipublikasikan: 30 September 2020

Cara sitasi: Rahmmatiya, R., \& Miatun, A. (2020). Analisis kemampuan pemecahan masalah matematis ditinjau dari resiliensi matematis siswa smp. Teorema: Teori dan Riset Matematika, 5(2), 187-202. 


\section{PENDAHULUAN}

Kemampuan pemecahan masalah sangat penting dalam pembelajaran matematika (Albay, 2019). Pada setiap kurikulum pembelajaran matematika tingkat sekolah selalu kompetensi dasar yang berhubungan dengan pemecahan masalah matematis (Akbar et al., 2017). Kurikulum 2013 revisi 2018 menekankan bahwa dalam setiap pembelajaran di sekolah bertujuan untuk meningkatkan kemampuan pemecahan masalah (Peraturan Menteri Pendidikan dan Kebudayaan Republik Indonesia Nomor 36 Tahun 2018). Selain adanya tuntutan kurikulum untuk mengembangkan kemampuan pemecahan masalah, ternyata di lapangan banyak guru yang kurang fokus pada pengembangan kemampuan pemecahan masalah (Habibatul \& Azizah, 2019). Hal ini menjadi salah satu dorongan untuk mengetahui bagaimana kemampuan pemecahan masalah siswa di sekolah.

Pemecahan masalah merupakan suatu usaha siswa dalam menyelesaikan masalah khususnya dalam pembelajaran matematika. Pemecahan masalah dalam pembelajaran matematika menekankan pada penggunaan metode, prosedur, dan strategi yang dapat dibuktikan kebenarannya secara sistematis. Dalam matematika istilah pemecahan masalah mengacu pada tugas-tugas yang diberikan untuk meningkatkan pemahaman dan kemampuan matematik siswa. Cai \& Leister (Albay, 2019) menyebutkan bahwa pemecahan masalah dapat membantu siswa mengembangkan kemampuan pemahaman konsep, koneksi, dan komunikasi matematisnya. Pehkonen (Siswono, 2016) menyebutkan bahwa kemampuan pemecahan masalah siswa penting untuk meningkatkan keterampilan kognitif dan dapat memotivasi siswa dalam belajar matematika. Selain itu kemampuan pemecahan masalah juga mendorong siswa untuk dapat menggunakan konsep dan strateginya sendiri dalam menyelesaikan masalah matematika yang diberikan (Intaros et al., 2014). Sejalan dengan Bayat \& Tarmizi (2010) yang menyebutkan bahwa dengan pemecahan masalah dapat meningkatkan kemampuan kognitif siswa.

Terdapat empat langkah pemecahan masalah yang disusun oleh Polya. Polya memperkenalkan model, prosedur ataupun langkah-langkah dalam pemecahan masalah yaitu: (1) memahami masalah; siswa perlu mengidentifikasi terlebih dahulu informasi dan apa yang ditanyakan dalam soal; (2) menyusun rencana; siswa menghubungkan pengetahuan yang telah dimiliki sebelumnya dengan informasi dan yang ditanyakan dalam soal; (3) melaksanakan rencana; selanjutnya siswa melaksanakan perhitungan/komputasi; dan (4) mengecek kembali; siswa melakukan koreksi ulang terhadap hasil penyelesaian masalah yang telah diperoleh (Zakiah et al., 2019). Pada setiap langkah yang sudah disebutkan, siswa diharapkan mampu menyusun strategi yang sesuai untuk menyelesaikan permasalahan yang dihadapi khususya dalam pembelajaran matematika. Pertama memahami masalah, pada langkah ini yaitu memahami dan mengidentifikasi apa informasi yang diberikan dan ditanyakan dalam suatu pertanyaan. Kedua merencanakan penyelesaian, pada langkah ini siswa memilih pendekatan atau strategi yang akan digunakan untuk menyelesaikan masalah pada pertanyaan. Ketiga menyelesaikan masalah sesuai rencana, pada langkah ini yaitu menerapkan strategi atau pendekatan yang telah direncanakan untuk mendapatkan solusi dari masalah tersebut dalam suatu pertanyaan. Keempat melakukan pengecekan kembali, pada langkah ini yaitu memeriksa kebenaran jawaban apakah memberikan pemecahan terhadap masalah yang termuat pada suatu pertayaan atau tidak.

Akbar et al. (2017) menyebutkan bahwa kemampuan pemecahan masalah siswa masih tergolong rendah. Hasil penelitiannya menyebutkan bahwa siswa dengan disposisi matematis rendah pencapaian indikator kemampuan pemecahan masalahnya masih belum maksimal. Hasil penelitian Puteha \& Ibrahim (2010) menyebutkan hanya sebagian kecil siswa memiliki kemampuan pemecahan masalah yang baik, siswa yang memiliki kemampuan pemecahan masalah yang baik menggunakan strategi tertentu dalam menyelesaikan masalah. Hadi \& Radiyatul (2014) menyebutkan bahwa dengan menggunakan langkah Polya kemampuan pemecahan masalah siswa menjadi meningkat. Dalam penelitian ini peneliti ingin mengkaji secara lebih mendalam bagaimana kemampuan pemecahan masalah matematis siswa berdasarkan langkah Polya. Prabawa (2017) meneliti kemampuan pemecahan masalah siswa jika ditinjau dari gaya kognitif, hasil penelitiannya menunjukkan bahwa pemecahan masalah siswa FI lebih baik daripada siswa FD. Sedangkan Eko et al. (2016) menyebutkan dalam hasil penelitiannya bahwa siswa memiliki kemampuan pemecahan masalah yang berbeda-beda dan cenderung masih 
rendah berdasarkan gaya belajarnya. Dari beberapa hasil penelitian di atas menunjukkan bahwa kemampuan pemecahan masalah masih perlu diteliti secara lebih mendalam lagi. Pada penelitian kali ini peneliti ingin melihat bagaimana kemampuan pemecahan masalah siswa jika dilihat dari resiliensi matematisnya.

Pemecahan masalah menjadi tujuan umum dalam pembelajaran matematika bahkan dikatakan sebagai jantungnya matematika dan menjadi dasar dalam pembelajaran matematika (Sariningsih \& Purwasih, 2017). Tercapai atau tidaknya tujuan pembelajaran matematika dapat dilihat dari keberhasilan siswa dalam memahami matematika dan memanfaatkan pemahaman matematika dalam menyelesaikan persoalan sehari-hari maupun dalam mempelajari ilmu pengetahuan lain. Dalam hal ini keberhasilan siswa dalam pembelajaran matematika tergantung bagaimana cara siswa menyelesaikan permasalahan soal karena tingkat kecerdasan siswa berbeda, ada yang memiliki kemampuan pecahan masalah matematik yang baik dan ada yang kurang. Siswa yang memiliki kemampuan pemecahan masalah yang baik tentunya mampu mengatasi kesulitan yang dihadapi dalam menyelesaikan pemecahan masalah, namun berbeda dengan siswa yang memiliki kemampuan pemecahan masalah yang rendah cenderung menganggap kesulitan yang dihadapi dalam menyelesaikan pemecahan masalah sebagai akhir dari perjuangan dan menyebabkan prestasi belajarnya menjadi rendah. Selain itu, berdasarkan hasil observasi yang dilakukan oleh peneliti pada siswa SMP, tingkat kemampuan pemecahan masalah siswa masih relatif rendah khusnya kelas VII-B, pada hasil nilai PTS (Penilaian Tengah Semester) siswa kelas VII-B yang mencapai KKM hanya $18 \%$ dan yang tidak mencapai KKM $82 \%$, peneliti juga mendapati bahwa kontrol diri sebagaian besar siswa dalam menghadapi pemecahan masalah matematis masih relatif lemah. Beberapa siswa ketika menghadapi kesulitan dalam memecahkan masalah khususnya dalam soal matematika, mereka cenderung tidak mau untuk berusaha bertanya kepada teman ataupun gurunya, mereka juga cenderung menghindari tugas-tugas yang sulit, hal ini disebabkan kurangnya kemampuan dan rasa percaya diri terhadap soal matematik yang mereka kerjakan dan pada akhirnya banyak siswa hanya menyalin pekerjaan teman yang mereka anggap pintar. Kurangnya kemampuan pemecahan masalah dan rasa percaya diri siswa dalam menghadapi permasalahan soal dapat menghambat prestasi akademiknya. Untuk mengatasinya diperlukan salah satu afeksi yang menunjang kemampuan pemecahan masalah yaitu resiliensi matematis.

Resiliensi merupakan sikap positif untuk membuat siswa tidak mudah menyerah dalam menghadapi kesulitan ketika memecahkan masalah matematika dengan melalui diskusi dan penyelidikan tentang matematika (Hafiz et al., 2017). Pentingnya resiliensi matematis ini dilihat dalam penelitian pendidikan matematika, karena siswa mengalami hambatan, kesulitan, dan kecemasan dalam belajar matematika, yang mengarah kepada ketidaksukaan siswa pada matematik (Sari et al., 2017; Zanthy, 2018). Hal ini menyebabkan siswa berusaha menghindari untuk mempelajari dan mengerjakan permasalahan soal matematika. Untuk menghadapi rasa cemas, takut dalam menghadapi tantangan dan kesulitan, memerlukan kerja keras dan kemampuan berbahasa yang baik, siswa perlu memiliki sikap tekun dan tangguh yang temuat dalam resiliensi matematis.

Resiliensi matematis adalah sikap bermutu dalam belajar matematika yang meliputi: percaya diri akan keberhasilannya melalui kerja kerasnya, menunjukkan ketekunan dalam menghadapi kesulitan, adanya keingginan untuk berdiskusi, merefleksi dan meneliti (Johnston-wilder \& Lee, 2010). Resiliensi matematis menjadi salah satu sikap faktor internal yang mempengaruhi keberhasilan seseorang dalam belajar matematik (Hidayat, 2017; Nurmasari, 2014). Dalam penelitian yang dilakukan oleh (Kurnia et al., 2018) menunjukkan bahwa siswa yang memiliki resiliensi tinggi ternyata dapat menyelesaikan soal matematis dengan baik, sedangan untuk siswa yang memiliki resiliensi rendah kurang tepat dalam menyelesaikan soal matematis. Andriani \& Nurjaman (2018) dalam penelitiannya memberikan hasil bahwa sebanyak $26 \%$ subjek penelitiannya memiliki resiliensi matematis tinggi, $57 \%$ sedang dan $15 \%$ memiliki resiliensi rendah. Seperti yang sudah disebutkan di atas bahwa resiliensi mempengaruhi keberhasilan seseorang dalam belajar. Hal ini sejalan dengan hasil penelitian dari Maharani \& Bernard (2018) yang menyebutkan bahwa terdapat hubungan yang signifikan antara kemampuan pemecahan masalah dengan resiliensi matematis. Selain itu resiliensi matematis juga berpengaruh terhadap kemampuan pemecahan 
matematis sebesar 32,7\% (Athiyah et al., 2020). Dilla et al. (2018) dalam hasil penelitiannya menyebutkan bahwa semakin tinggi tingkat resiliensi matematis siswa maka semakin tinggi kemampuan berpikir kreatifnya. Resiliensi dapat membantu siswa mengatasi kesulitan dalam pemecahan masalah matematis (Maharani \& Bernard, 2018).

Adapun resiliensi matematis dalam penelitian ini diadaptasi dari indikator resiliensi matematis menurut Sumarmo (Hendriana et al., 2017) yaitu: (a) menunjukkan sikap tekun, yakin/percaya diri, bekerja keras, serta tidak mudah menyerah menghadapi masalah kegagalan dan ketidakpastian; (b) menunjukkan keinginan bersosialisasi, mudah memberi bantuan, berdiskusi dengan teman sebaya; (c) memunculkan ide/cara baru dengan mencari solusi kreatif terhadap tantangan; (d) menggunakan pengalaman kegagalan untuk membangun motivasi diri; (e) memiliki rasa ingin tahu, merefleksi, meneliti, dan memanfaatkan beragam sumber; dan (f) memiliki kemampuan mengontrol diri; sadar akan perasaannya.

Berdasarkan uraian di atas kemampuan pemecahan masalah matematis merupakan kemampuan yang sangat penting dimiliki siswa, karena kemampuan pemecahan masalah matematis menjadi tujuan umum dalam pembelajaran metematika (Sariningsih \& Purwasih, 2017). Beberapa penelitian di atas mengemukakan bahwa resiliensi matematis mempengaruhi tingkat kemampuan pemecahan masalah matematis siswa. Oleh karena itu terdapat dugaan bahwa resiliensi matematis dapat menunjang kemampuan pemecahan masalah matematis siswa. Penelitian ini bertujuan untuk mendeskripsikan dan menganalisis kemampuan pemecahan masalah matematis siswa SMP bila ditinjau dari resiliensi matematisnya.

\section{METODE PENELITIAN}

Penelitian ini menggunakan metode penelitian deskriptif kualitatif. Penelitian dilakukan di SMP Negeri 160 Jakarta. Sebelum dilaksanakan penelitian, peneliti memilih 30 orang siswa kelas VII-B sebagai calon subjek. Instrumen dalam penelitian ini berupa angket resiliensi matematis, tes kemampuan pemecahan masalah matematis dan pedoman wawancara.

Instrumen angket resiliensi matematis berupa angket sebanyak 37 butir dengan pernyataan positif dan negatif yang diadaptasikan dari indikator Sumarmo yaitu: (1) menunjukkan sikap tekun, yakin/percaya diri, bekerja keras dan tidak mudah menyerah dalam menghadapi masalah, kegagalan, dan ketidak pastian; (2) menunjukkan keinginan bersosialisasi, mudah memberi bantuan, berdiskusi dengan sebayanya, dan beradaptasi dengan lingkungannya; (3) memunculkan ide/cara baru dan mencari solusi yang kreatif dengan tantangan; (4) menggunakan pengalaman kegagalan untuk membangun motivasi diri; (5) memiliki rasa ingin tahu, merefleksi, meneliti, dan memanfaatkan beragam sumber; dan (6) memiliki kemampuan berbahasa, mengontrol diri, sadar akan perasaannya. Sedangkan untuk instrumen tes kemampuan pemecahan masalah matematis sebanyak 5 butir soal berdasarkan langkah-langkah Polya yaitu: (1) memahami masalah; (2) merencanakan penyelesaian; (3) menyelesaikan masalah sesuai rencana; dan (4) melakukan pengecekan kembali.

Teknik wawancara dalam penelitian ini menggunakan metode semi terstruktur. Wawancara semi terstruktur merupakan proses wawancara yang menggunakan pedoman wawancara namun lebih fleksibel sehingga peneliti bisa bertanya di luar pedoman wawancara namun tidak boleh diluar topik yang ingin diteliti. Wawancara dilakukan dengan bertanya kepada subjek penelitian yang telah dikategorikan tingkat resiliensi matematis sebelumnya, adapun pertanyaan yang diajukan peneliti terkait tes kemampuan pemecahan masalah matematis yang sudah dikerjakan sebelumnya. Hal ini bertujuan mendapatkan informasi yang berkaitan dengan data yang dibutuhkan dalam penelitian ini yaitu kemampuan pemecahan masalah matematis bila ditinjau resiliensi matematisnya.

Untuk pengambilan data peneliti mengujicobakan angket resiliensi matematis, dalam setiap pernyataan skala resiliensi matematis mempunyai lima pilihan jawaban yaitu: sangat tidak setuju (STS), tidak setuju (ST), netral (N), setuju (S), dan sangat setuju (SS). Setelah angket diujicobakan kemudian hasilnya dianalisis untuk mengkatagorikan siswa yang memiliki resiliensi matematis tinggi, sedang, dan rendah. Adapun pemberian skor angket/kuesioner resiliensi matematis untuk pernyataan positif STS $=1$, 
$S T=2, N=3, S=4, S S=5$, sedangkan pernyataan negatif bernilai sebaliknya yaitu $S T S=5, S T=4, N=$ $3, S=2, S S=1$.

Menurut Sriffudin (Kurnia et al., 2018) untuk menentukan pengkategorian skala resiliensi matematis dalam penelitian diperlukan mencari nilai terendah dan tertinggi, kemudian mencari mean ideal $(M)$ dengan rumus $\frac{1}{2} \times$ (nilai tertinggi + nilai terendah), dan mencari standar deviasi (SD) dengan rumus $\frac{1}{6} \times$ (nilai tertinggi - nilai terendah). Pengkategorian resiliensi matematis disajikan pada Tabel 1.

Tabel 1. Kategori resiliensi matematis

\begin{tabular}{ccc}
\hline Respon jenis pertanyaan & Skor positif & Skor negatif \\
\hline$X \geq(M+1 S D)$ & $X \geq 136$ & Resiliensi tinggi \\
$(M-1 S D) \leq X<(M+1 S D)$ & $86 \leq X<136$ & Resiliensi sedang \\
$X<(M-1 S D)$ & $X<86$ & Resiliensi rendah \\
\hline
\end{tabular}

Subjek dalam penelitian ini dipilih untuk setiap kategori menggunakan teknik purposive sampling. Pemilihan subjek pada penelitian ini dilihat dari siswa yang memiliki tingkatan resiliensi yang berbeda tetapi mempunyai nilai awal yang sama, dalam hal ini peneliti memilih nilai PTS (Penilaian Tengah Semester) sebagai nilai awal siswa. Subjek yang terpilih kemudian diberikan tes kemampuan pemecahan masalah matematis dan diwawancarai berdasarkan tes yang telah dikerjakan sebelumnya. Untuk menguji keabsahan data, peneliti menggunakan triangulasi data yaitu triangulasi waktu, dengan memberikan tes kemampuan pemecahan masalah matematis yang sama dalam waktu yang berbeda.

Analisis data penelitian ini menggunakan metode perbandingan tetap (constant comperative method). Analisis data dilakukan dengan membandingkan secara tetap satu datum dengan datum lainnya, kemudian secara tetap membandingkan kategori dengan kategori lainnya (Moleong, 2017). Langkah dalam analisis data meliputi: (1) reduksi data dan kategori dengan memilih data sesuai dengan apa yang diteliti dan membuang data yang tidak diperlukan pada proses analisis data; (2) penyajian data, dimana data yang sudah direduksi disajikan sesuai dengan kebutuhan dalam menganalisis kemampuan pemecahan masalah berdasarkan resiliensi matematis siswa SMP; dan (3) penarikan kesimpulan dan verifikasi, dimana data yang sudah disajikan kemudian dibandingkan serta dianalisis berdasarkan indikator tes kemampuan pemecahan masalah matematis dan disesuaikan dengan tingkat resiliensi matematis yang dimiliki subjek penelitian.

\section{HASIL DAN PEMBAHASAN HASIL}

Setelah angket resiliensi diujikan pada 30 siswa, kemudian peneliti mengkategorikan siswa yang memiliki resiliensi tingkat tinggi, sedang dan rendah. Hasil tingkatan resiliensi metamatis siswa disajikan pada Tabel 2.

Tabel 2. Data hasil resiliensi matematis

\begin{tabular}{cc}
\hline Tingkat resiliensi matematis & Jumlah siswa \\
\hline Tinggi & 8 \\
Sedang & 22 \\
\hline
\end{tabular}

Berdasarkan Tabel 2 di atas maka diperoleh tingkatan resiliensi matematis siswa Kelas VII-B SMP Negeri 160 Jakarta. Siswa yang memiliki tingkat resiliensi tinggi sebanyak 8 orang atau $27 \%$ siswa, sedangkan siswa yang memliki tingkat resiliensi sedang sebanyak 22 orang atau $73 \%$ siswa.

Setelah mengkategorikan hasil angket resiliensi matematis, selanjutnya dipilih 1 subjek untuk masing-masing kategori siswa yang memiliki resiliensi tinggi dan sedang. Subjek dipilih menggunakan metode purposive sampling, dalam hal ini peneliti menentukan pengambilan subjek dengan cara menetapkan kategori khusus yang sesuai dengan tujuan penelitian. Subjek dengan 
kategori resiliensi matematis tinggi yang terpilih adalah siswa yang bernama TAR yang selanjutnya akan dikodekan dengan nama subjek S1. Sedangkan untuk subjek dengan kategori resiliensi sedang yang terpilih adalah siswa yang bernama TGAMS yang selanjutnya akan dikodekan dengan nama subjek S2. Kedua subjek terpilih berjenis kelamin perempuan.

Data hasil penelitian ini merupakan hasil pengerjaan Tes Kemampuan Pemecahan Masalah Matematis (TKPMM) dan data wawancara. Data hasil wawancara setiap subjek ditranskipkan dan dipaparkan untuk mengetahui kemampuan pemecahan masalah matematis siswa. Untuk memudahkan penulisan pada paparan hasil wawancara, peneliti membuat kode "Px, y, z" dan "Sx, y, $z$ ". $P$ = Pewawancara; $S=$ Subjek penelitian; $x, y, z=$ kode digit pada $P$ dan $S$, dimana digit pertama menyatakan subjek ke- $x(1 \leq x \leq 2)$, sedangkan digit kedua menyatakan wawancara berbasis tugas ke-y $(1 \leq y \leq 2)$, dan digit ketiga menyatakan urutan pertanyaaan atau jawaban ke-z. Berikut merupakan contoh penggunaan kode tersebut:

P1.1.1 = Pewawancara pada subjek 1, wawancara berbasis tugas ke 1 dan pertanyaan ke-1.

S1.1.1 = Subjek S1, wawancara berbasis tugas ke-1 dan jawaban ke-1.

Adapun kode untuk subjek penelitian:

Subjek S1 = Siswa yang memiliki Resiliensi Tinggi

Subjek S2 = Siswa yang memiliki Resiliensi Sedang

Berikut disajikan paparan data hasil tes tertulis dan data wawancara pada TKPMM1 dan TKPMM2 untuk subjek yang memiliki resiliensi tinggi (subjek S1) dan subjek yang memiliki resiliensi sedang (subjek S2).

\section{Subjek S1 dengan Resiliensi Matematis Tinggi}

Pertanyaan nomor 1 pada TKPMM 1 sebagai berikut: "Diketahui perbandingan diagonaldiagonal belahketupat berbanding 3:4. Jika luas belahketupat adalah $384 \mathrm{~cm}^{2}$. Hitunglah keliling belahketupat tersebut!". Pertanyaan nomor 1 pada TKPMM 1 dan TKPMM 2 pada dasarnya merupakan pertanyaan yang sama hanya saja dibedakan pada perbandingan diagonal-diagonal belahketupat dan luas belahketupat.

Subjek S1 dalam menjawab soal TKPMM nomor 1 kurang teliti, tetapi menuliskan jawaban dengan secara rinci dan dilengkapi dengan gambar. Subjek S1 dapat menerjemahkan informasi yang diperoleh dari pertanyaan nomor 1 . Rencana pelaksanaan dijabarkan dengan baik oleh subjek $\mathrm{S1}$, dan menggunakan rumus sesuai yang ditanyakan, tetapi ada kekeliruan terhadap penulisan rumus phytagoras pada lembar jawaban subjek S1 seharusnya $c^{2}=a^{2}+b^{2}$, tetapi subjek $S 1$ menuliskannya $a^{2}=b^{2}+c^{2}$. Penyelesaian yang dilakukan subjek $S 1$ sesuai dengan apa yang ditanyakan pada pertanyaan nomor 1 . Subjek $\mathrm{S} 1$ memeriksa kembali penyelesaian soal yang sudah dikerjakan. Subjek S1 sudah mampu memenuhi langkah-langkah yang sistematis dalam memecahkan masalah, karena penyelesaian yang dikerjakan sesuai dengan urutan langkah-langkah penyelesaian masalah, yaitu dengan membuat apa yang diketahui dan apa yang ditanyakan, membuat rencana masalah yang dikerjakan mulai dari memahami masalah, membuat pelaksanaan penyelesaian, dan memeriksa kembali hasil pengerjaannya. Subjek S1 juga sudah mampu memecahkan masalah, tetapi kurang teliti dalam pengerjaan yang dilakukan karena terdapat kesalahan penulisan pada rumus phytagoras.

Berikut data jawaban subjek S1 disajikan pada Gambar 1 dan Gambar 2 beserta cuplikan wawancara pada pertanyaan soal nomor 1 untuk subjek S1 yang disajikan pada Tabel 3. 


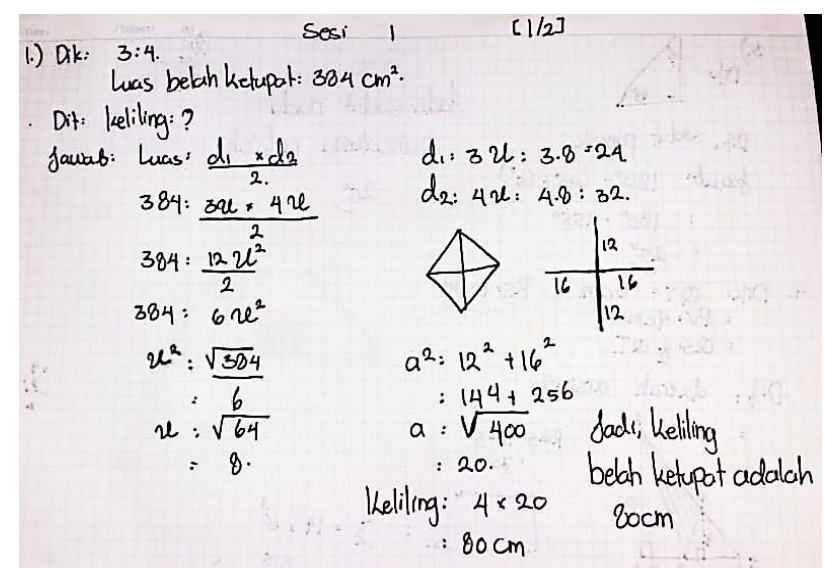

Gambar 1. Hasil tes tertulis subjek S1 pertanyaan nomor 1 pada TKPMM 1
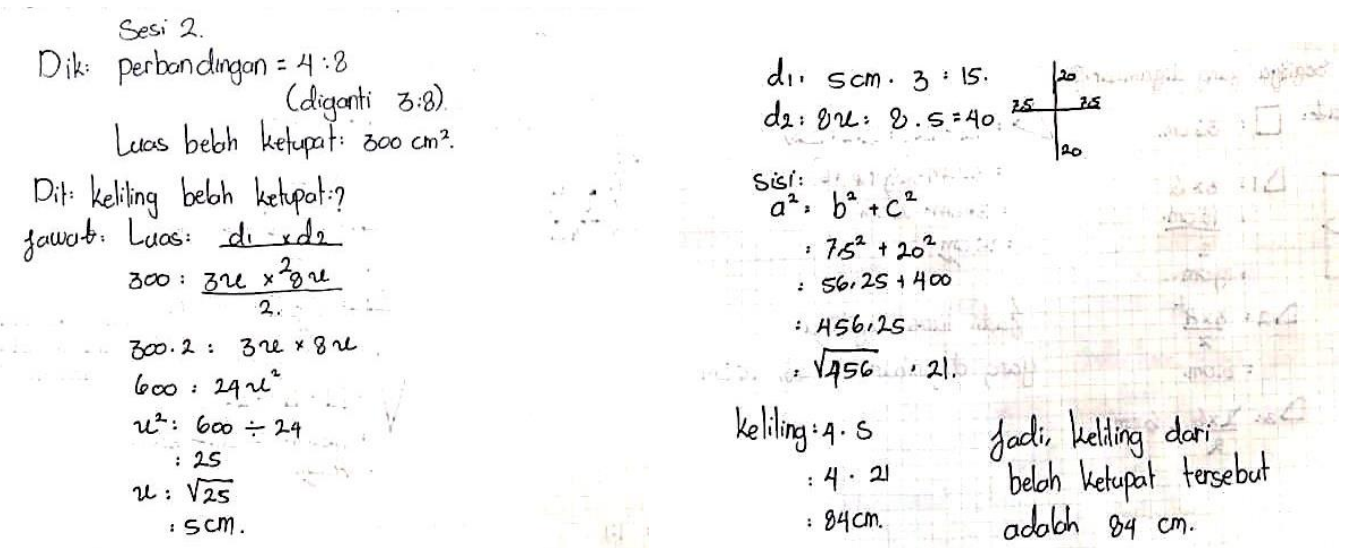

Gambar 2. Hasil tes tertulis S1 pertanyaan nomor 1 pada TKPMM 2

Dari Gambar 1 dan Gambar 2 menunjukkan bahwa jawaban tertulis subjek S1 pada TKPMM 1 dan TKPMM 2 cenderung konsisten dan memakai cara yang sama, sehingga dapat dinyatakan bahwa data pertanyaan untuk nomor 1 adalah valid.

Tabel 3. Hasil cuplikan wawancara subjek S1 pada TKPMM 1 dan TKPMM 2

\section{TKPMM 1}

P1.1.11 Untuk mencari diagonal belahketupat apa yang kamu lakukan?

S1.1.11 Aku misalkan perbandingan diagonalnya jadi $3 x$ untuk d1 dan $4 x$ untuk d2, setelah itu aku cari nilai $x$ dari luasnya pake rumus mencari luas belahketupat, abis itu aku masukan nilai $x$ yang sudah didapat pada diagonalnya yang aku misalkan tadi untuk mendapatkan nilai diagonal belah ketupat.

P1.1.12 Setelah itu, bagaimana cara kamu mencari keliling belahketupat seperti yang di tanyakan pada soal?

S1.1.12 Sebelum aku cari keliling aku cari sisinya dulu, untuk mencari sisi aku pake rumus phytagoras, setelah aku hitungkan dapat tuh sisinya, abis itu aku masukin ke rumus keliling.

P1.1.13 Apakah kamu memeriksa kembali jawaban kamu untuk nomor 1 ?

S1.1.13 lya bu, saya memeriksa kembali, takut ada yang salah, tapi saya yakin benar sih.

\section{TKPMM 2}

P1.2.11 Untuk mencari diagonal belahketupat apa yang kamu lakukan?

S1.2.11 Sama kayak cara yg sebelumnya aku misalkan perbandingan diagonalnya untuk dapatin nilai diagonal belah ketupat.

P1.2.12 Kan di soal ditanya keliling belahketupat, nah gimana cara kamu mencarinya?

S1.2.12 Cari sisi dulu baru kelilingknya, mencari sisinya aku pake rumus phytagoras sama yang kayak jawaban aku sebelumnya, cuma kali ini aku ga suka sama angkanya karena koma, kan udah dapat tuh sisinya baru aku cari keliling belah ketupat.

P1.2.13 Apa alasan kamu menggunakan rumus phytagoras untuk mecari sisi belah ketupat

S1.2.13 Kan sisi belahketupat itu berbentuk segitiga sikusiku dengan setengah diagonalnya, jadi aku pake phytagoras untuk mencari sisi miring yang sebagai sisi belah ketupatnya.

P1.2.14 Apakah kamu memeriksa kembali jawaban kamu untuk nomor 1 ?

S1.2.14 lya bu. 
Berdasarkan hasil wawancara pada Tabel 3, terlihat bahwa subjek S1 mampu menjelaskan setiap langkah jawaban yang dituliskan dengan baik dan pecaya diri atas jawaban yang telah dikerjakannya.

Pada pertanyaan nomor selanjutnya dalam menjawab pertanyaan nomor 2, dan 3, dan 4 . Subjek S1 mampu memahami masalah dan menerjemahkan informasi yang terdapat pada setiap pertanyaan, dengan selalu menuliskan apa yang diketahui dan ditanyakan dalam pertanyaan. Rencana pelaksanaan dijabarkan dengan baik dan rinci. Rumus yang digunakan sesuai dengan yang ditanyakan. Subjek S1 sudah mampu mencapai langkah-langkah yang sistematis dalam memecahkan masalah, karena penyelesaian yang dikerjakan sesuai dengan urutan langkah-langkah penyelesaian masalah, yaitu memahami masalah dengan menuliskan apa yang diketahui dan apa yang ditanyakan, membuat rencana masalah yang dikerjakan, membuat pelaksanaan penyelesaian, dan memeriksa kembali hasil pengerjaannya. Pada dasarnya pada TKPMM 1 dan TKPMM 2 merupakan pertanyaan yang sama hanya angka yang membedakan. Subjek pada TKPMM 1 dan TKPMM 2 selalu konsisten dan memakai cara yang sama dalam menjawab pertanyaan yang ditanyakan, sehingga dapat dinyatakan bahwa data pertanyaan untuk nomor 2, 3, dan 4 adalah valid. Ketika dilakukan wawancara mengenai jawaban yang telah dituliskan, subjek S1 mampu menjelaskan dengan baik dan jelas, bahkan dengan percaya diri subjek S1 menjelaskan secara rinci setiap langkah yang dikerjakannya.

Pertanyaan nomor 5 pada TKPMM 1 sebagai berikut: "Perhatikan gambar di bawah ini!. Nani menggambar sebuah segitiga pada selembar kertas yang berbentuk persegi seperti yang ditunjukkan gambar dibawah ini. Tentukanlah luas segitiga yang digambar oleh Nani!". Pertanyaan nomor 5 pada TKPMM 1 dan TKPMM 2 pada dasarnya merupakan pertanyaan yang sama.

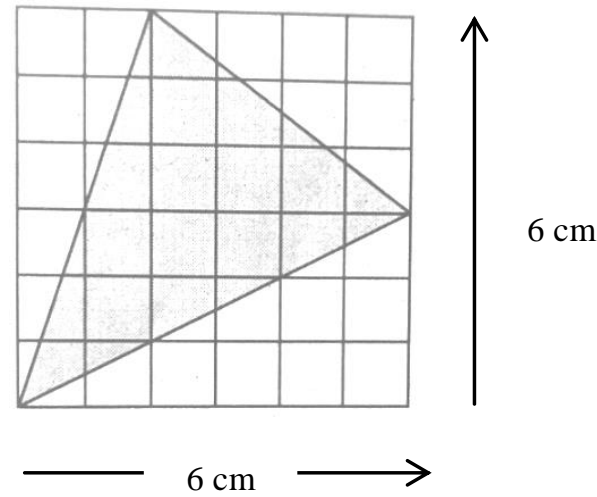

Gambar 3. Gambar pertanyaan nomor 5

Subjek S1 dalam menjawab soal TKPMM nomor 5 lebih teliti dan dilengkapi dengan gambar. Subjek S1 dapat menerjemahkan informasi yang diperoleh dengan menuliskan apa yang diketahui dan ditanyakan dari pertanyaan nomor 5 . Rencana pelaksanaan dijabarkan dengan baik oleh subjek S1, dan menggunakan rumus sesuai yang ditanyakan. Penyelesaian yang dilakukan subjek S1 sesuai dengan apa yang ditanyakan pada pertanyaan nomor 5. Subjek S1 memeriksa kembali penyelesaian soal yang sudah dikerjakan dan membuat kesimpulan dari jawaban yang diperoleh. Dalam hal ini Subjek S1 sudah mampu memenuhi langkah-langkah yang sistematis dalam memecahkan masalah, karena penyelesaian yang dikerjakan sesuai dengan urutan langkah-langkah penyelesaian masalah mulai dari memahami masalah, membuat rencana masalah yang dikerjakan, membuat pelaksanaan penyelesaian, dan memeriksa kembali hasil pengerjaannya. Subjek S1 sudah mampu memecahkan masalah karena teliti dalam pengerjaan yang dilakukan, dengan memeriksa kembali dan membuat kesimpulan dari jawaban yang diperoleh. Berikut data jawaban subjek S1 disajikan pada Gambar 4 dan Gambar 5. 
5.) Dik: 1:1: $6 \mathrm{~cm}: 6 \mathrm{~cm}$

Dit: Segitiga yang digambar:?

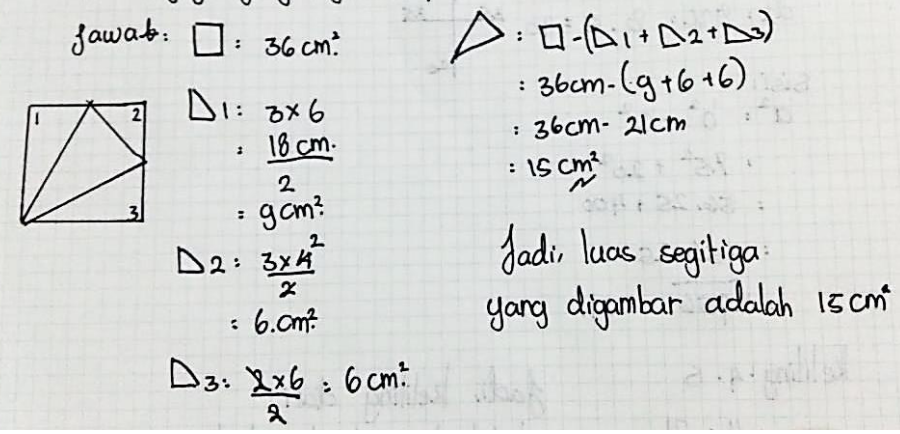

Gambar 4. Hasil tes tertulis S1 pertanyaan nomor 5 pada TKPMM 1

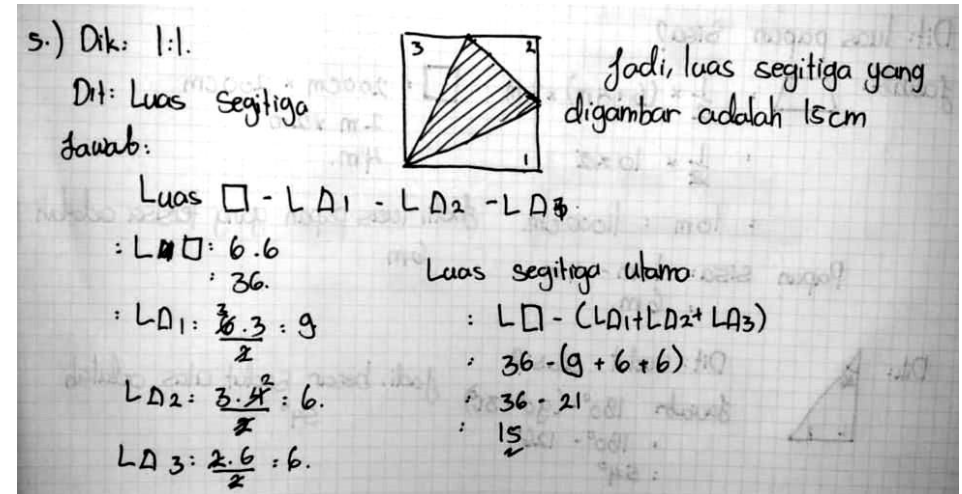

Gambar 5. Hasil tes tertulis $\mathrm{S} 1$ pertanyaan nomor 5 pada TKPMM 2

Dari Gambar 4 dan Gambar 5 menunjukkan bahwa jawaban tertulis subjek S1 pada TKPMM 1 dan TKPMM 2 cenderung konsisten dan memakai cara yang sama, sehingga dapat dinyatakan bahwa data untuk pertanyaan nomor 5 adalah valid. Ketika dilakukan wawancara terkait jawaban tertulis yang sudah dikerjakannya, subjek S1 mampu menjelaskan dengan jelas dan percaya diri setiap langkah yang dikerjakannya.

\section{Subjek S2 dengan Resiliensi Matematis Sedang}

Pertanyaan nomor 1 pada TKPMM 1 dan TKPMM 2 pada dasarnya merupakan pertanyaan yang sama hanya saja dibedakan pada perbandingan diagonal-diagonal belahketupat dan luas belahketupat. Subjek S2 dalam menjawab pertanyaan nomor 1 pada TKPMM kurang teliti, tidak memahami konsep dan cenderung menghafal rumus hal ini diakuinya pada saat wawancara berlangsung, sehingga menyebabkan subjek S2 kesulitan menjawab soal yang serupa. Dalam menjawab pertanyaan nomor 1 subjek S2 sudah memenuhi langkah-langkah yang sistematis dalam memecahkan masalah, subjek S2 dapat menerjemahkan informasi yang diperoleh dari pertanyaan nomor 1 dengan menuliskan apa yang diketahui dan ditanyakan. Rencana pelaksanaan dijabarkan dengan cukup baik oleh subjek S2 dan menggunakan rumus sesuai yang ditanyakan tetapi kurang lengkap. Penyelesaian yang dilakukan subjek S2 sesuai dengan apa yang ditanyakan pada pertanyaan nomor 1 . Subjek S2 pada TKPMM 1 memeriksa kembali jawaban yang telah dikerjakan. Dalam hal ini subjek S2 sudah mencapai langkah-langkah yang sistematis dalam memecahkan masalah, penyelesaian yang dikerjakan sudah sesuai dengan urutan langkah-langkah penyelesaian masalah mulai dari memahami masalah, membuat pelaksanaan penyelesaian, dan memeriksa kembali hasil pengerjaannya. Pada TKPMM 2 subjek S2 tidak memeriksa kembali jawaban karena sudah yakin salah pada jawaban yang sudah dikerjakan, karena subjek S2 tidak memeriksa kembali jawaban yang telah dikerjakannya maka jawabannya yang didapat kurang tepat pada TKPMM 2 untuk nomor 1, subjek S2 juga kurang mampu memecahkan masalah karena kurang teliti dan cenderung menghafal rumus tanpa memahami konsep matematika sehingga ketika diberikan soal 
yang serupa subjek S2 tidak mampu mengerjakannya, bila dihadapkan soal sulit siswa cenderung menyerah dan tidak percaya diri terhadap pertanyaan dikerjakannya.

Berikut data jawaban subjek S2 disajikan pada Gambar 6 dan Gambar 7 beserta cuplikan wawancara pada pertanyaan soal nomor 1 untuk subjek S2 yang disajikan pada Tabel 4.

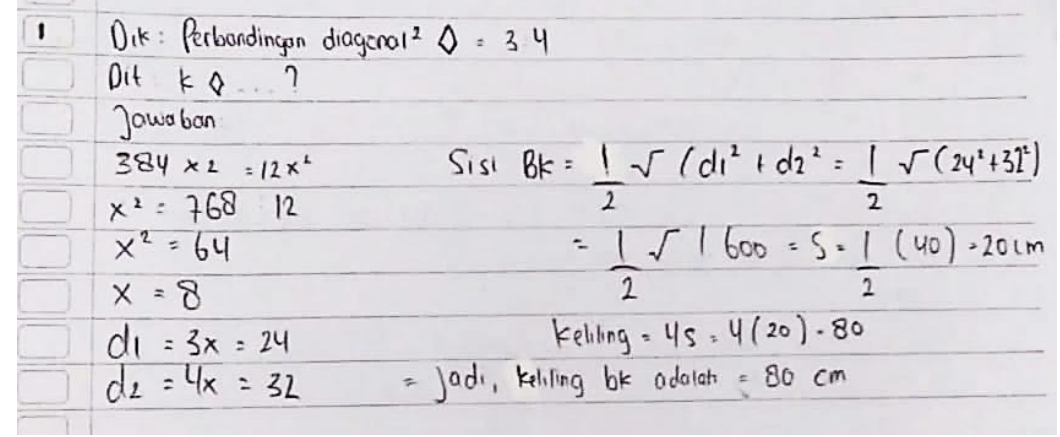

Gambar 6. Hasil tes tertulis S2 pertanyaan nomor 1 pada TKPMM 1

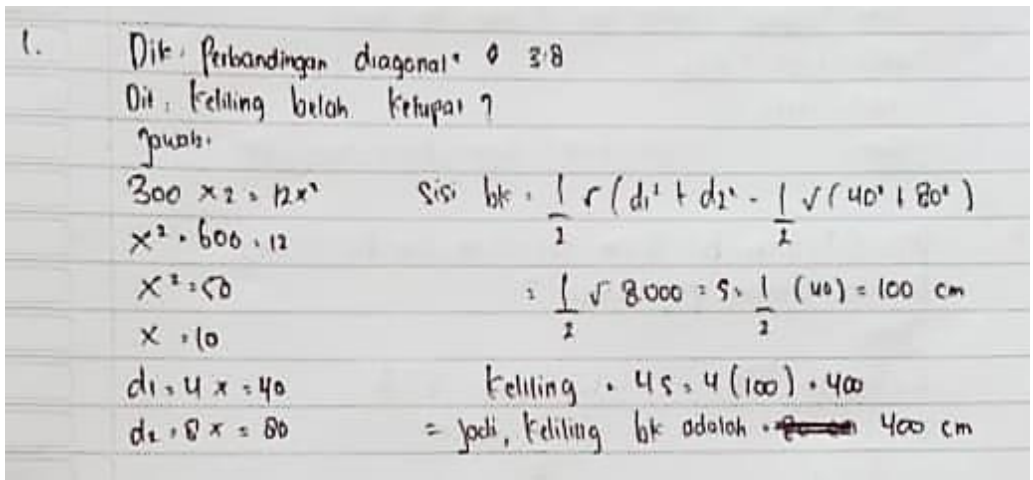

Gambar 7. Hasil tes tertulis S2 pertanyaan nomor 1 pada TKPMM 2

Dari Gambar 6 dan Gambar 7 menunjukkan bahwa jawaban tertulis subjek S2 pada TKPMM 1 dan TKPMM 2 cenderung konsisten dan memakai cara yang sama, sehingga dapat dinyatakan bahwa data pada pertanyaan nomor 1 adalah valid.

Tabel 4. Hasil cuplikan wawanacara subjek S2 pada TKPMM 1 dan TKPMM 2

\begin{tabular}{|c|c|c|c|}
\hline \multicolumn{2}{|r|}{ TKPMM 1} & \multicolumn{2}{|r|}{ TKPMM 2} \\
\hline P2.1.11 & $\begin{array}{l}\text { Untuk mencari diagonal belah ketupat apa yang } \\
\text { kamu lakukan? }\end{array}$ & P2.2.11 & $\begin{array}{l}\text { Untuk mencari diagonal belah ketupat apa } \\
\text { yang kamu lakukan? }\end{array}$ \\
\hline S2.1.11 & $\begin{array}{l}\text { Kan yang diketahui perbandingan diagonal } \\
\text { belahketupat, terus aku misalin jadi } 3 x \text { dan } 4 x \text {, } \\
\text { abis itu cari nilainya } x \text { nya pakai luas yang udah } \\
\text { diketahui, setelah itu masukin nilai } x \text { ke } \\
\text { diagonalnya, ketemu deh nilai diagonal d1 dan }\end{array}$ & S2.2.11 & $\begin{array}{l}\text { Sama kayak cara kemarin, aku misalin } \\
\text { diagonalnya jadi } 3 x \text { dan } 4 x \text {, abis itu cari } \\
\text { nilai } x \text {, terus untuk cari diagonal aku } \\
\text { masukin nilai } x \text { ke perbandingan diagonal } \\
\text { yang aku misalkan tadi. }\end{array}$ \\
\hline & d2. & P2.2.12 & Coba jelaskan cara kamu mencari sisi \\
\hline P2.1.12 & Mencari nilai $\mathrm{x}$ nya kata kamu menggunakan & & belah ketupat? \\
\hline & luas, maksudnya gimana tuh? & S2.2.12 & Untuk mencari sisi aku menggunakan \\
\hline S2.1.12 & $\begin{array}{l}\text { lya, jadi pake rumus mencari luas belahketupat, } \\
\text { tapi dijawaban aku ga nulis rumusnya langsung } \\
\text { aku hitung aja. }\end{array}$ & & $\begin{array}{l}\text { rumus yang aku ingat waktu SD, jujur soal } \\
\text { yang kedua ini agak susah, dan aku } \\
\text { bingung menghitung sisi belahketupat }\end{array}$ \\
\hline P2.1.13 & $\begin{array}{l}\text { Gimana cara kamu mencari keliling belah } \\
\text { ketupat? }\end{array}$ & & $\begin{array}{l}\text { karena hasil akhirnya setengah akar } 8000 \text {, } \\
\text { karena aku ga tau akhirnya saya ngasal. }\end{array}$ \\
\hline S2.1.13 & $\begin{array}{l}\text { Aku cari sisinya dulu, untuk mencarinya aku } \\
\text { pakai rumus yang aku dapat dulu waktu kelas } 4\end{array}$ & & $\begin{array}{l}\text { Maaf yah bu, kalau salah soalnya saya } \\
\text { gatau. }\end{array}$ \\
\hline & $\begin{array}{l}\text { SD, setelah dapat sisinya baru aku cari } \\
\text { kelilingnya. }\end{array}$ & P2.2.13 & $\begin{array}{l}\text { Apakah kamu memeriksa kembali jawaban } \\
\text { kamu untuk nomor } 1 \text { ? }\end{array}$ \\
\hline P2.1.14 & $\begin{array}{l}\text { Apakah kamu memeriksa kembali jawaban } \\
\text { kamu untuk nomor } 1 \text { ? }\end{array}$ & S2.2.13 & Tidak bu, karena saya yakin salah. \\
\hline S2.1.14 & $\begin{array}{l}\text { lyaa bu saya periksa kembali, soalnya saya } \\
\text { yakin benar bu tapi gatau juga sih. }\end{array}$ & & \\
\hline
\end{tabular}


Berdasarkan hasil wawancara pada Tabel 4, terlihat bahwa subjek S2 cukup baik dalam menjelaskan setiap langkah dari hasil jawaban tertulisnya, hanya adanya kurang rasa percaya diri dalam memberikan jawaban, dan pada saat wawancara subjek S2 mengakui kalau pada TKPMM 2 untuk pertanyaan nomor 1 kurang teliti, dan yakin kalau jawabannya salah sehingga enggan untuk memeriksa kembali jawaban yang sudah dikerjakan sebelumnya.

Pada pertanyaan nomor selanjutnya, nomor 2, 3, dan 4. Subjek S2 mampu memahami masalah dan menerjemahkan informasi yang terdapat pada setiap pertanyaan, dengan selalu menuliskan apa yang diketahui dan ditanyakan dalam pertanyaan. Rencana pelaksanaan dijabarkan dengan baik dan rinci. Rumus yang digunakan sesuai dengan yang ditanyakan. Subjek S2 sudah mampu mencapai langkah-langkah yang sistematis dalam memecahkan masalah, karena penyelesaian yang dikerjakan sesuai dengan urutan langkah-langkah penyelesaian masalah mulai dari memahami masalah, membuat apa yang diketahui dan apa yang ditanyakan, membuat rencana masalah yang dikerjakan, membuat pelaksanaan penyelesaian, tetapi subjek S2 ini hanya memeriksa kembali jawaban yang dia yakini benar, karena pada pertanyaan nomor 2, 3 dan 4 dia yakini benar maka subjek S2 memeriksa kembali jawabannya dan menuliskan kesimpulan dari jawaban yang sudah diperoleh. Dalam hal ini subjek S2 sudah mencapai langkah-langkah yang sistematis dalam memecahkan masalah dan ketika dilakukan wawancara terkait jawaban yang sudah dikerjakan, subjek S2 cenderung tidak percaya diri dalam menjawab setiap pertanyaan yang diajukan.

Pertanyaan nomor 5 pada TKPMM 1 dan TKPMM 2 pada dasarnya merupakan pertanyaan yang sama. Subjek S2 dalam menjawab pertanyaan nomor 5 pada TKPMM kurang teliti, serta tidak memahami dan tidak mampu menerjemahkan informasi pada pertanyaan nomor 5 , hal ini dibuktikan dengan siswa belum mampu menuliskan apa yang diketahui pada pertanyaan nomor 5 . Rencana pelaksanaan tidak dijabarkan dengan baik oleh subjek S2, kemudian penggunaan rumus yang kurang tepat dalam menjawab penyelesaian masalah, penyelesaian soal yang dilakukan subjek S2 tidak sesuai apa yang ditanyakan. Subjek S2 tidak memeriksa kembali jawaban yang telah dikerjakannya, tetapi subjek S2 membuat kesimpulan dari jawaban yang diperoleh. Dalam hal ini subjek S2 belum mencapai langkahlangkah yang sistematis dalam menyelesaikan masalah, karena penyelesaian yang dikerjakan belum sesuai dengan urutan langkah-langkah penyelesaian masalah. Berikut data jawaban subjek S1 disajikan pada Gambar 8 dan Gambar 9.

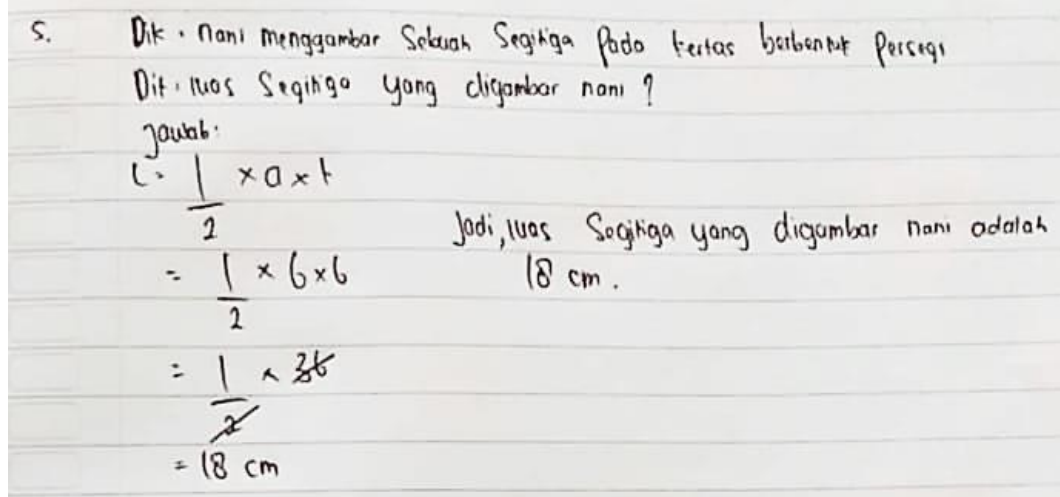

Gambar 8. Hasil tes tertulis S2 pertanyaan nomor 5 pada TKPMM 1 


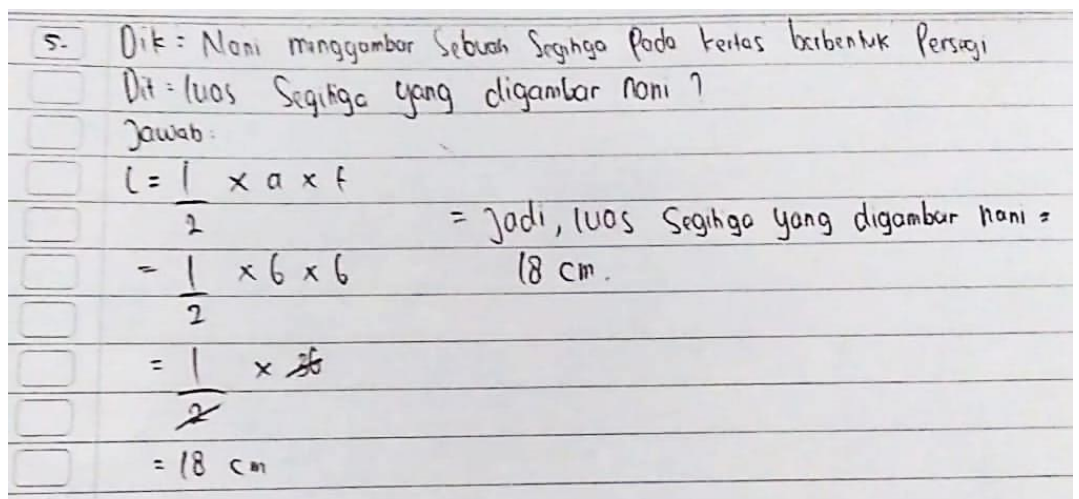

Gambar 9. Hasil tes tertulis S2 pertanyaan nomor 5 pada TKPMM 2

Dari Gambar 8 dan Gambar 9 menunjukkan bahwa jawaban tertulis subjek S2 pada TKPMM 1 dan TKPMM 2 cenderung konsisten dan memakai cara yang sama, sehingga dapat dinyatakan bahwa data pada pertanyaan nomor 5 adalah valid. Ketika diwawancara subjek S2 mengaku tidak bisa mengerjakan pertanyaan nomor 5 sehingga memilih untuk menyerah dan tidak memeriksa kembali jawaban yang sudah dikerjakan karena sudah yakin bahwa jawabannya salah.

\section{PEMBAHASAN}

Hasil penelitian yang sudah dijelaskan adalah hasil subjek $\mathbf{S 1}$ yang memiliki resiliensi tinggi mampu menjawab tes kemampuan pemecahan masalah matematis dengan baik dan mencapai langkah-langkah yang sistematis dalam memecahkan masalah. Ketika dilakukan wawancara subjek S1 mampu menjelaskan langkah-langkah penyelesaian masalah pada setiap pertanyaan yang sudah dikerjakannya dengan percaya diri, jelas dan rinci. Sedangkan untuk subjek S2 yang memiliki resiliensi sedang kurang baik dalam menjawab tes kemampuan pemecahan masalah matematis, hal ini dibuktikan kurang telitinya dalam menjawab pertanyaan, cederung menyerah bila dihadapkan soal yang sulit dan enggan memeriksa kembali bila ia menyakini bahwa soal yang dikerjakannya salah. Ada beberapa soal dimana jawaban subjek S2 belum mencapai langkah-langkah yang sistematis dalam memecahkan masalah. Ketika dilakukan wawancara subjek S2 tersebut cenderung kurang percaya diri tehadap pertanyaan yang diajukan. Hal ini sejalan dengan penelitian yang dilakukan oleh Kurnia et al. (2018) menunjukkan bahwa siswa yang memiliki resiliensi tinggi ternyata dapat menyelesaikan soal matematis dengan baik, sedangkan untuk siswa yang memiliki resiliensi rendah kurang tepat dalam menyelesaikan soal matematis.

Untuk lebih jelasnya, berikut disajikan pada Tabel 5 mengenai deskripsi dari kemampuan pemecahan masalah matematis berdasarkan resiliensi matematis:

Tabel 5. Deskripsi kemampuan pemecahan masalah berdasarkan resiliensi matematis

\begin{tabular}{|c|c|}
\hline Subjek S1 (Resiliensi tinggi) & Subjek S2 (Resiliensi sedang) \\
\hline \multicolumn{2}{|c|}{ Pertanyaan Nomor 1} \\
\hline $\begin{array}{l}\text { Pada pertanyaan nomor } 1 \text { untuk TKPMM } 1 \text { dan TKPMM } 2 \\
\text { sudah mampu memenuhi langkah-langkah yang } \\
\text { sistematis mulai dari memahami masalah subjek S1 } \\
\text { mampu menerjemahkan informasi mulai dengan } \\
\text { menuliskan apa yang ditanya dan diketahui pada } \\
\text { pertanyaan nomor 1, kemudian merencanakan } \\
\text { penyelesaian, menyelesaikan masalah yang sesuai } \\
\text { dengan pertanyaan nomor } 1 \text { dan terakhir memeriksa } \\
\text { kembali jawaban yang sudah dikerjakan. Ketika dilakukan } \\
\text { wawancara subjek S1 mampu menjesalakan setiap } \\
\text { langkah penyelesaian dengan jelas, rinci dan percaya diri. }\end{array}$ & $\begin{array}{l}\text { Pada pertanyaan nomor } 1 \text { untuk TKPMM } 1 \text { sudah } \\
\text { mampu memenuhi langkah-langkah yang sistematis } \\
\text { mulai dari memahami masalah subjek S2 mampu } \\
\text { menerjemahkan informasi mulai dengan menuliskan } \\
\text { apa yang diketahui dan ditanya pada pertanyaan } \\
\text { nomor } 1 \text {, kemudian merencanakan penyelesaian, } \\
\text { menyelesaikan masalah yang sesuai dengan } \\
\text { pertanyaan nomor } 1 \text {, dan terakhir memeriksa kembali } \\
\text { jawaban yang sudah dikerjakan. Tetapi ketika } \\
\text { diberikan soal yang serupa pada TKPMM } 2 \text { subjek S2 } \\
\text { tidak mampu mengerjakan pertanyaan nomor } 1 \\
\text { karena subjek S2 cenderung menghafal rumus tanpa } \\
\text { memahami konsep matematika. Hal ini terlihat pada } \\
\text { lembar jawaban subjek S2 dan hasil wawancara }\end{array}$ \\
\hline
\end{tabular}


Lanjutan Tabel 5.

Tabel 5. Deskripsi kemampuan pemecahan masalah berdasarkan resiliensi matematis Subjek S1 (Resiliensi tinggi) Subjek S2 (Resiliensi sedang)

Pertanyaan Nomor 1

ketika dihadapkan soal yang sulit siswa cenderung menyerah dan enggan untuk memeriksa kembali karena sudah yakin jawabannya salah. Ketika dilakukan wawancara subjek S2 mampu menjelaskan setiap langkah penyelesaian dengan cukup baik, namun kurang percaya diri.

Pertanyaan Nomor 2

Pada pertanyaan nomor 2 untuk TKPMM 1 dan TKPMM 2 Pada pertanyaan nomor 2 untuk TKPMM 1 dan sudah mampu memenuhi langkah-langkah yang TKPMM 2 sudah mampu memenuhi langkah-langkah sistematis mulai dari memahami masalah subjek $\mathrm{S} 1$ mampu menerjemahkan informasi mulai dengan menuliskan apa yang ditanya dan diketahui pada pertanyaan nomor 2, kemudian merencanakan penyelesaian, menyelesaikan masalah yang sesuai dengan pertanyaan nomor 2 dan terakhir memeriksa kembali jawaban yang sudah dikerjakan. Ketika dilakukan wawancara subjek S1 mampu menjelaskan setiap langkah penyelesaian dengan jelas, rinci dan percaya diri. yang sistematis mulai dari memahami masalah. Subjek S2 mampu menerjemahkan informasi mulai dengan menuliskan apa yang ditanya dan diketahui pada pertanyaan nomor 2 , kemudian merencanakan penyelesaian, menyelesaikan masalah yang sesuai dengan pertanyaan nomor 2 dan terakhir memeriksa kembali jawaban yang sudah dikerjakan. Ketika dilakukan wawancara subjek S2 mampu menjelaskan setiap langkah penyelesaian dengan jelas, rinci, dan percaya diri.

Pertanyaan Nomor 3

Pada pertanyaan nomor 3 untuk TKPMM 1 dan TKPMM 2 Pada pertanyaan nomor 3 untuk TKPMM 1 dan sudah mampu memenuhi langkah-langkah yang TKPMM 2 sudah mampu memenuhi langkah-langkah sistematis mulai dari memahami masalah subjek $\mathrm{S} 1$ yang sistematis mulai dari mamahami masalah subjek mampu menerjemahkan informasi mulai dengan S2 mampu menerjemahkan informasi mulai dengan menuliskan apa yang ditanya dan diketahui pada pertanyaan nomor 3, kemudian merencanakan penyelesaian, menyelesaikan masalah yang sesuai dengan pertanyaan, dan terakhir memeriksa kembali jawaban yang sudah dikerjakan. Ketika dilakukan wawancara subjek S1 mampu menjelaskan setiap langkah penyelesaian dengan jelas, rinci, dan percaya diri. menuliskan apa yang ditanya dan diketahui pada pertanyaan nomor 3, kemudian merencanakan penyelesaian, menyelesaikan masalah yang sesuai dengan pertanyaan, dan terakhir memeriksa kembali jawaban yang sudah dikerjakan. Ketika dilakukan wawancara subjek S2 kurang menjelaskan setiap langkah penyelesaian dan cenderung kurang percaya diri dalam memberikan jawaban.

Pertanyaan Nomor 4

Pada pertanyaan nomor 4 untuk TKPMM 1 dan TKPMM 2 Pada pertanyaan nomor 4 untuk TKPMM 1 dan subjek S1 memberikan jawaban yang unik dalam TKPMM 2 pada dasarnya soal yang sama, Pada menjawab soal tetapi jawaban yang diberikan kurang pertanyaan nomor 4 untuk TKPMM 1 dan TKPMM 2 tepat, dan siswa sudah mampu memenuhi langkahlangkah yang sistematis mulai dari memahami masalah, siswa mampu menerjemahkan informasi mulai dengan menuliskan apa yang diketahui dan ditanyakan pada pertanyaan nomor 4, kemudian merencanakan penyelesaian, menyelesaikan masalah yang sesuai dengan pertanyaan, dan terakhir memeriksa kembali jawaban yang sudah dikerjakan. Ketika dilakukan wawancara subjek $\mathrm{S1}$ mampu menjelaskan setiap langkah penyelesaian dengan jelas, rinci, dan percaya diri. sudah mampu memenuhi langkah-langkah yang sistematis mulai dari mamahami masalah subjek S2 mampu menerjemahkan informasi mulai dengan menuliskan apa yang diketahui dan ditanyakan pada pertanyaan nomor 4, kemudian merencanakan penyelesaian, menyelesaikan masalah yang sesuai dengan pertanyaan nomor dan terakhir memeriksa kembali jawaban yang sudah dikerjakan. Ketika dilakukan wawancara subjek S2 mampu menjesalakan setiap langkah penyelesaian dengan jelas, rinci, dan percaya diri.

Pertanyaan Nomor 5

Pada pertanyaan nomor 5 untuk TKPMM 1 dan TKPMM 2 Pada pertanyaan nomor 5 untuk TKPMM 1 dan pada dasarnya merupakan pertanyaan yang sama. Pada pertanyaan nomor 5 subjek S1 sudah mampu memenuhi langkah-langkah yang sistematis mulai dari mamahami TKPMM 2 pada dasarnya merupakan pertanyaan yang sama. Pada pertanyaan nomor 5 untuk TKPMM 1 dan TKPMM 2 belum mampu memenuhi langkahmasalah.Subjek S1 mampu menerjemahkan informasi

langkah yang sistematis dalam kemampuan 
Lanjutan Tabel 5.

Tabel 5. Deskriptif dari kemampuan pemecahan masalah berdasarkan resiliensi matematis Subjek S1 (Resiliensi tinggi) Subjek S2 (Resiliensi sedang)

Pertanyaan Nomor 5

mulai dengan menuliskan apa yang diketahui dan ditanyakan pada pertanyaan nomor 5 , kemudian merencanakan penyelesaian, menyelesaikan masalah yang sesuai dengan pertanyaan nomor dan terakhir memeriksa kembali jawaban yang sudah dikerjakan. Ketika dilakukan wawancara subjek S1 mampu menjelaskan setiap langkah penyelesaian dengan jelas, rinci, dan percaya diri.

masalah karena subjek S2 belum mampu menerjemahkan informasi. Hal ini dibuktikan dengan subjek S2 belum mampu menuliskan apa yang di ketahui pada pertanyaan nomor 5 , dan dalam merencanakan penyelesaian serta menyelesaikan masalah belum sesuai dengan pertanyaan nomor 5 . Ketika dilakukan wawancara subjek S2 mengaku enggan memeriksa kembali jawaban karena sudah yakin bahwa jawabannya salah. Subjek S2 juga belum mampu menjawab setiap langkah penyelesaian dengan baik serta kurang percaya diri dalam memberikan jawaban.

Dari penyajian Tabel 5 di atas terlihat bahwa subjek S1 yang memiliki resiliensi tinggi mampu mengerjakan tes kemampuan pemecahan masalah dengan baik dan percaya diri dalam menjawab setiap pertanyaannya. Sedangkan untuk subjek S2 yang memiliki resiliensi sedang, cukup baik dalam menjawab tes kemampuan pemecahan masalah, tetapi adanya rasa kurang percaya diri dan cenderung menyerah dalam menjawab pertanyaan yang dianggapnya sulit. Subjek S1 mampu mencapai langkah-langkah yang strategis dalam memecahkan masalah pada setiap pertanyaan. Sama hal seperti yang dikemukan oleh Polya yaitu: (1) memahami masalah; (2) merencanakan penyelesaian; (3) menyelesaikan masalah sesuai rencana; dan (4) melakukan pengecekan kembali. Menjadi catatan peneliti bahwa kemampuan pemecahan masalah matematis siswa perlu ditingkatkan dengan memperhatikan tingkat resiliensi matematis siswa. Seperti hal tujuan dalam penelitian ini yaitu menganalisis kemampuan pemecahan masalah matematis siswa berdasarkan resiliensi matematis siswa, maka penelitian ini bisa menjadi landasan sekaligus bagi para guru untuk lebih meningkatkan kemampuan pemecahan masalah matematis siswa dengan memperhatikan tingkatan resiliensi matematis yang siswa miliki.

\section{KESIMPULAN}

Dari hasil penelitian yang telah diuraikan, maka dapat disimpulkan bahwa: (1) tidak terdapat siswa kelas VII-B yang memliki resiliensi rendah, hanya terdapat dua kategori siswa yang memiliki resiliensi tinggi dan sedang; (2) siswa yang memiliki resiliensi tinggi memiliki kemampuan pemecahan masalah matematis yang baik dan percaya diri bila dihadapkan berbagai permasalahan soal; dan (3) siswa yang memiliki resiliensi sedang, masih kurang dalam kemampuan pemecahan masalah matematisnya, karena belum mampu mencapai langkah-lagkah yang sistematis dalam kemampuan pemecahan masalah matematis, kurang teliti, dan cendrung menyerah bila dihadapkan soal yang sulit.

\section{REKOMENDASI}

Informasi pada artikel ini dapat dijadikan rujukan bagi peneliti dan mahasiswa untuk penilaian kemampuan pemecahan masalah matematis berdasarkan resiliensi matematis siswa SMP.

\section{DAFTAR PUSTAKA}

Akbar, P., Hamid, A., Bernard, M., \& Sugandi, A. I. (2017). Analisis kemampuan pemecahan masalah dan disposisi matematik siswa kelas xi sma putra juang dalam materi peluang. Jurnal Cendekia: Jurnal Pendidikan Matematika, 2(1), 144-153. https://doi.org/10.31004/cendekia.v2i1.62. 
Albay, E. M. (2019). Analyzing the effects of the problem solving approach to the performance and attitude of first year university students. Social Sciences \& Humanities Open, 1(1), 100006. https://doi.org/10.1016/j.ssaho.2019.100006

Andriani, D., \& Nurjaman, A. (2018). Analisis kemampuan pemahaman konsep materi segitiga dan segiempat pada siswa SMP. Jurnal Pembelajaran Matematika Inovatif, 1(2), 1015-1026. https://doi.org/10.22460/jpmi.v1i3.219-228.

Athiyah, F., Umah, U., \& Syafrudin, T. (2020). Pengaruh mathematical resilience terhadap kemampuan pemecahan masalah matematis siswa. Jurnal Kajian Pendidikan Matematika, 2682(2), 223-234.

Bayat, S., \& Tarmizi, R. A. (2010). Assessing cognitive and metacognitive strategies during algebra problem solving among university students. Procedia-Social and Behavioral Sciences, 8(5), 403-410. https://doi.org/10.1016/j.sbspro.2010.12.056.

Dilla, S. C., Hidayat, W., \& Rohaeti, E. E. (2018). Faktor gender dan resiliensi dalam pencapaian kemampuan berpikir kreatif matematis siswa SMA. Journal of Medives: Journal of

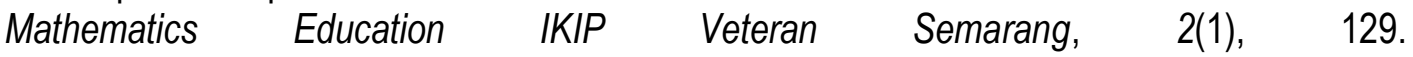
https://doi.org/10.31331/medives.v2i1.553.

Eko, B., Riau, S., Junaedi, I., \& Artikel, I. (2016). Analisis kemampuan pemecahan masalah matematik siswa kelas vii berdasarkan gaya belajar pada pembelajaran PBL. Unnes Journal of Mathematics Education Research, 5(2), 166-177.

Habibatul, I. K., \& Azizah, M. (2019). Analisis kemampuan penalaran siswa dalam pemecahan masalah matematika siswa kelas iv. Indonesian Journal of Educational Research and Review, 2(2), 210-218. https://doi.org/10.23887/ijerr.v2i2.17629.

Hadi, S., \& Radiyatul, R. (2014). Metode pemecahan masalah menurut polya untuk mengembangkan kemampuan siswa dalam pemecahan masalah matematis di sekolah menengah pertama. EDU-MAT: Jurnal Pendidikan Matematika, 2(1), 53-61. https://doi.org/10.20527/edumat.v2i1.603.

Hafiz, M., Darhim, \& Dahlan, J. A. (2017). Comparison of mathematical resilience among students with problem based learning and guided discovery learning model. Journal of Physics: Conference Series. https://doi.org/10.1088/1742-6596/895/1/012098.

Hendriana, H., Rohaeti, E. E., \& Sumarmo, U. (2017). Hard skills dan soft skills matematis siswa. Refika Aditama.

Hidayat, W. (2017). Adversity quotient dan penalaran kreatif matematis siswa sma dalam pembelajaran argument driven inquiry pada materi turunan fungsi. KALAMATIKA Jurnal Pendidikan Matematika. https://doi.org/10.22236/kalamatika.vol2no1.2017pp15-28.

Intaros, P., Inprasitha, M., \& Srisawadi, N. (2014). Students' problem solving strategies in problem solving-mathematics classroom. Procedia - Social and Behavioral Sciences, 116, 4119-123. https://doi.org/10.1016/j.sbspro.2014.01.901.

Johnston-wilder, S., \& Lee, C. (2010). Developing mathematical resilience. BERA Conference 1st 4th September 2010, University of Warwick, September. 
Kurnia, H. I., Royani, Y., Hendiana, H., \& Nurfauziah, P. (2018). Analisis kemampuan komunikasi matematik siswa smp ditinjau dari resiliensi matematik. Jpmi. https://doi.org/10.22460/jpmi.v1i5.p933-940.

Maharani, S., \& Bernard, M. (2018). Analisis hubungan resiliensi matematik terhadap kemampuan pemecahan masalah siswa pada materi lingkaran. JPMI (Jurnal Pembelajaran Matematika Inovatif), 1(5), 819. https://doi.org/10.22460/jpmi.v1i5.p819-826.

Moleong, L. J. (2017). Metodologi penelitian kualitatif (edisi revisi). Bandung: PT. Remaja Rosda Karya.

Nurmasari, N. (2014). Analisis berpikir kreatif siswa dalam menyelesaikan masalah matematika pada materi peluang ditinjau dari gender siswa kelas xi IPA sma negeri 1 Kota Banjarbaru Kalimantan Selatan. Pediatric Physical Therapy. https://doi.org/10.1016/s10137025(09)70018-1.

Peraturan Menteri Pendidikan dan Kebudayaan Republik Indonesia Nomor 36 Tahun 2018, Permendikbud 1 (2018).

Prabawa, E. A. (2017). Analisis kemampuan pemecahan masalah ditinjau dari gaya kognitif siswa pada model project based learning bernuansa etnomatematika. Unnes Journal of Mathematics Education Research, 6(1), 120-129.

Puteha, M., \& Ibrahim, M. (2010). The usage of self-regulated learning strategies among form four students in the mathematical problem-solving context: A case study. Procedia - Social and Behavioral Sciences, 8(5), 446-452. https://doi.org/10.1016/j.sbspro.2010.12.061.

Sari, I. P., Purwasih, R., \& Nurjaman, A. (2017). Analisis hambatan belajar mahasiswa pada mata kuliah program linear. JIPM (Jurnal IImiah Pendidikan Matematika). https://doi.org/10.25273/jipm.v6i1.1569.

Sariningsih, R., \& Purwasih, R. (2017). Pembelajaran problem based learning untuk meningkatkan kemampuan pemecahan masalah matematis dan self efficacy mahasiswa calon guru. JNPM (Jurnal Nasional Pendidikan Matematika). https://doi.org/10.33603/jnpm.v1i1.275.

Siswono, T. Y. E. (2016). Meningkatkan kemampuan berpikir kreatif siswa melalui pengajuan masalah matematika. Edumath, 1-10.

Zakiah, N. E., Sunaryo, Y., \& Amam, A. (2019). Implementasi pendekatan kontekstual pada model pembelajaran berbasis masalah berdasarkan langkah-langkah polya. Teorema: Teori dan Riset Matematika, 4(2), 111-120.

Zanthy, L. S. (2018). Kontribusi resiliensi matematis terhadap kemampuan akademik mahasiswa pada mata kuliah statistika matematika. Mosharafa: Jurnal Pendidikan Matematika. https://doi.org/10.31980/mosharafa.v7i1.344. 